\title{
ECOLOGY OF THE fREe LIVING STAGES OF CATTLE NEMATOdES DURINg SUmmer contamination in Argentina Western Pampas
}

\author{
SUAREZ V.H.* \& LORENZO R.L.*
}

\section{Summary :}

Development, migration and survival of infective larvae $\left(L_{3}\right)$ were studied in the Western Pampeana Region. Faeces of naturally nematode infected cattle were deposited as artificial pats on plots during mid-spring-summer of 1994/1995 and 1995/1996. Since the start and during 1995, the study coincided with a severe drought, rainfalls being $29 \%$ below the 45 -year means. The predominant genera recovered were Cooperia, Ostertagia and Haemonchus. Initial and peak recovery of $L_{3}$ from pats occurred 8-15 and 15-21 days later respectively. A low percentage of $L_{3}$ survived from November $\left(0.3 \% L_{3}\right)$ and January $\left.10.06 \% L_{3}\right)$ to the following autumn and winter. The mean persistence of larvae detected in pats or herbage was around 200 days from deposition. The migration of $\mathrm{L}_{3}$ from faecal pats to herbage started 15 to 30 days after deposition according to rainfall occurrence. Maximum herbage recoveries of $\mathrm{L}_{3}$ from pats deposited in late summer occur during autumn rainfalls. Only, few $L_{3}$ were occasionally recovered from soil. Summer conditions were associated with rapid development and translation of $L_{3}$ to herbage, but also with low $L_{3}$ detection after initial recoveries. Faecal pats deposited from mid-summer were the main source of autumn herbage contamination.

KEY WORDS : cattle, nematode, free-living stages, development and survival, Argentina's Pampas.
Résumé : ÉCOLOGIE DES STADES LIBRES DE STRONGLES DIGESTIFS DES bovins au Cours de la CONTAMination estivale dans la Pampa DE L'OUEST DE L'ARGENTINE

Le développement, la migration et la survie des larves infestantes $\left(L_{3}\right)$ ont été étudiés dans la partie ovest de la Pampa Argentine. Des fèces de bovins naturellement infestés ont été déposées sous forme de bouses reconstituées sur des parcelles du milieu, du printemps à l'été en 1994/1995 et 1995/1996. Au début de l'étude et au cours de 1995, une sécheresse exceptionnelle a sévi, les pluies étant de $29 \%$ inférieures à la moyenne des 45 dernières années. Les principaux genres de nématodes rencontrés étaient Cooperia, Ostertagia et Haemonchus. Le début et le pic de récolte de $L_{3}$ à l'extérieur des bouses ont eu lieu respectivement 8-15 et 15-21 jours après le dépôt. Un faible pourcentage de $L_{3}$ a survécu de novembre $(0,3 \%$ ) et janvier $10,06 \%$ jusqu'à l'automne et l'hiver suivant. La persistence moyenne de récolte de $L_{3}$ dans les bouses a été de 200 jours après le dépôt. La migration des $L_{3}$ des fèces vers l'herbe a commencé 15 à 30 jours après le dépot, en fonction de la pluviométrie. Le maximum de $L_{3}$ sur l'herbe à partir des dépôts de fin d'été a été observé lors des pluies d'automne. De faibles taux de récolte de $L_{3}$ ont été obtenus occasionnellement à partir d'échantillons de sol. Les conditions estivales ont été associées à un développement et un déplacement rapides des larves des fèces vers I'herbe, mais aussi à des faibles nombres de $L_{3}$ récupérées après le début de leur détection. Les fèces déposées à partir du milieu de l'été étaient la source principale de contamination des herbages en automne.

MOTS CLÉS : bovin, nématode, stade larvaire libre, développement et survie, Pampa, Argentine.

grated strategies combining anthelmintic treatment with appropriate grazing management implies high epidemiological knowledge. A part of the cycle of these trichostrongylids occurs outside the host and is dependent upon the external environment conditions. The process whereby nematode eggs in faecal pats become infective larvae available for cattle is very important for the understanding of the epidemiology of nematode infection. Therefore, a detailed understanding of the dynamics of larvae populations on the environment is required before management control procedures can be recommended with confidence. In this region infective larvae availability for cattle is highest during autumn (Suarez, 1990). However, the source of these larvae was not investigated and is difficult to estimate because the amount of larvae is the result of conti-
* Estación Experimental Agropecuaria Anguil, Instituto Nacional de Tecnología Agropecuaria, CC 11, 6326 Anguil, La Pampa, Argentina. Correspondence: V.H. Suarez.

Tel./Fax: 542954495057 - E-mail: vsuarez@anguil.inta.gov.ar 
nuous faecal contamination, larvae development and mortality. In other countries, studies show that dung pats provides a favourable environment for free living stage survival under dry conditions during summer (Durie, 1961; Young \& Anderson, 1981). In the eastern Humid Pampeana Region of Argentina, Steffan \& Fiel (1986) showed that infective larvae survived in pats or herbage around 5-14 months from deposition. However, the climatic conditions and grass management of the western Pampeana Region differ considerably from those of the humid eastern region and local studies are necessary to understand the ecology of cattle nematode.

As no information was available in this semiarid part of the Pampeana region, the aim of the present study is to determine under natural condition on pasture plots, the contribution made by eggs deposited during mid-spring and summer to larvae availability and to estimate the development, migration and survival of nematode larvae in the faecal pats, herbage and soil.

\section{MATERIALS AND METHODS}

\section{EXPERIMENTAL DESIGN}

The experiment was conducted on the INTA Anguil Experimental Station field at La Pampa province of Argentina from November 1994 until June 1996. In eight trials, dung pats containing gastrointestinal nematode eggs were placed on experimental plots on 30-Nov of 1994, 16-Jan, 28-Feb, 20-Mar, 12-Oct, 12-Dec during 1995, 20-Feb, 19-Mar during 1996. The study was made on a sandy soil covered with lucerne, bromegrass and other natural grasses, which has not been grazed by cattle for at least 10 years.

Experimental rectangular plots of $5 \mathrm{~m} \times 1.5 \mathrm{~m}$ of side surrounded with small ditches were made to deposit the experimental faecal pats. Plot herbage was mown to a height of $16-20 \mathrm{~cm}$ and subsequently maintained. The faeces were taken from 87 (1994), 155 (1995) and 122 (1996) fattening growing calves from eight to 18 months of age, naturally infected with prevalent gastrointestinal nematodes. These animals kept as donors were representative of the fattening system of the region and reflect the general pattern of the parasites (Suarez, 1990).

Faeces were thoroughly mixed and weighed out into $800 \mathrm{~g}$ masses which were shaped into pats of $20 \mathrm{~cm}$ in diameter and $8 \mathrm{~cm}$ of high. In each trial 30 pats were placed on the plots and spaced $50 \mathrm{~cm}$ apart.

At the beginning of each trial, faecal pat samples were examined at eight days after faeces were deposited, then every three days and once the infective larvae was detected in the pat, the faecal pats and surrounded herbage and soil were examined at the $7^{\text {th }}, 15^{\text {th }}$ and $30^{\text {th }}$ day and then at monthly intervals. Moreover, another samples were taken during the trial after each rainfall. Faecal pat, herbage or soil sampling of a trial was discontinued after three successive recoveries of zero larvae. For each examination date, six samples of $5 \mathrm{~g}$ from different shaped faecal pats were taken at random and the mean value of the larvae recovered per $g$ were calculated. For recovery nematode infective larvae from herbage, the grass samples were taken at random, on a ratio of $25 \mathrm{~cm}$ around the faecal pats. Five pinches of grass around each faecal pat were taken until arise 100 samples (around $25 \mathrm{~g}$ of grass dry matter). Soil cores of $5 \mathrm{~cm}$ were removed near the faecal pats.

\section{PARASITOLOGICAL MEASUREMENTS}

At the beginning of each series, estimates of the donor calves contamination were made from three egg counts of mixed faecal pats, according with the method of Roberts \& O'Sullivan (1949), and specific infective larval $\left(\mathrm{L}_{3}\right)$ differentiation after culture of faecal samples (Suarez, 1997). All faecal pat of $5 \mathrm{~g}$ and soil samples of $10 \mathrm{~g}$ were subjected to Baermann (1917) modified technique (Suarez, 1997) for 24 hours and examined microscopically to determine number per $g$ and species of infective larvae. Pasture samples were cut to ground level and up to a height of $20 \mathrm{~cm}$. Nematode larvae of these samples were recovered and counted as larvae per dry matter (Suarez, 1997).

\section{METEOROLOGICAL MEASUREMENTS}

Daily rainfall, evaporation, relative humidity, maximum and minimum temperature were recorded from the Department of Meteorology of INTA Anguil, near the experimental side. The faecal water content from each faecal pat sample collection was measured by weighing $10 \mathrm{~g}$ before and after drying for $5 \mathrm{~h}$ at $100^{\circ} \mathrm{C}$.

\section{RESULTS}

The annual rainfall in this region ranged between 650 and $700 \mathrm{~mm}$; the highest incidence occurs from October (spring) to April (autumn). The mean maximum summer temperature reaches $30^{\circ} \mathrm{C}$ and the mean winter minimum temperature falls to $0^{\circ} \mathrm{C}$. At the end of 1994 and during 1995, the study coincided with a severe drought, as rainfalls were $29 \%$ below the 45-year means (Fig. 1), and environmental relative humidity was $19.7 \%$ below the 26-year means. From the spring of 1994 to the end of 1995 the temperatures and the evaporation rates exceeded average values, with $2^{\circ} \mathrm{C}$ and $19.8 \%$ above the last 35 -years average, fundamentally during the springs. The faecal pats usually lost 23 to $50 \%$ of their weight 
within the first 8-12 days after the deposition. After two months of environment exposure, the weight loss of the pats was 56 to $77 \%$.

The level of nematode infections of donor cattle were very low and faecal counts were below 75 epg. Faecal samples egg counts exceeded the 130 epg only during 1995 March and October.

\section{GENERA OF INFECTIVE LARVAE}

The predominant genera recovered from culture of faecal samples from the donor cattle were Cooperia ( $43 \%)$ and Ostertagia (30\%) during the spring (Table I) and Haemonchus (54\%) and Ostertagia (23\%) during the summer months (Table II). Trichostrongylus, and Oesophagostomum were the other genera recovered.

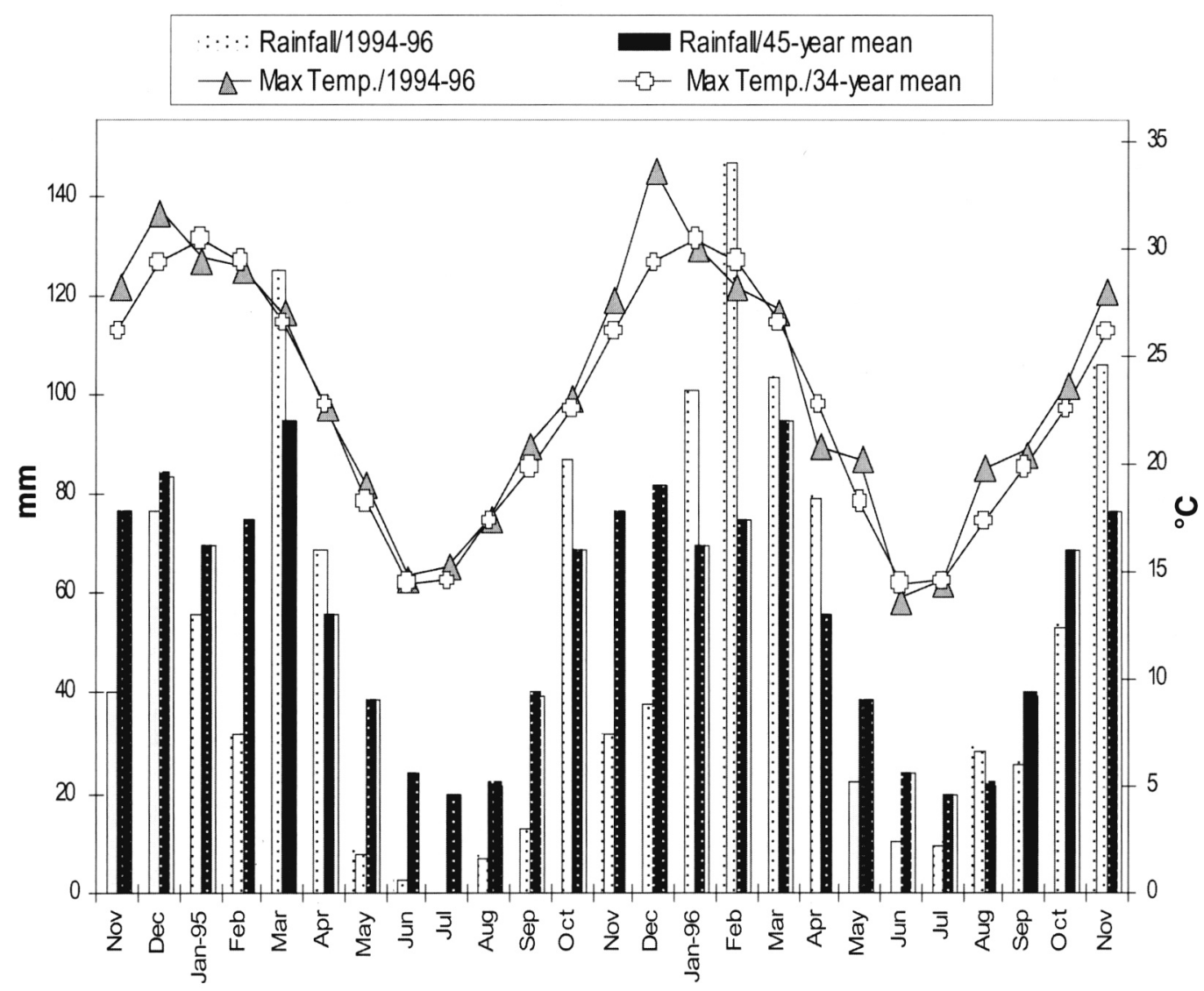

Fig. 1. - Mean monthly maximum temperature and rainfall compared with 34-year average and 45 year average respectively.

\begin{tabular}{|c|c|c|c|c|c|c|c|c|c|c|}
\hline \multirow[b]{2}{*}{ Faecal culture } & \multicolumn{2}{|c|}{ Ostertagia } & \multicolumn{2}{|c|}{ Cooperia } & \multicolumn{2}{|c|}{ Trichostro.* } & \multicolumn{2}{|c|}{ Haemoncbus } & \multicolumn{2}{|c|}{ Oesophag. ${ }^{*}$} \\
\hline & \multicolumn{2}{|c|}{30} & \multicolumn{2}{|c|}{43} & \multicolumn{2}{|c|}{13} & \multicolumn{2}{|c|}{8} & \multicolumn{2}{|c|}{6} \\
\hline & $\mathrm{FPL}_{3}$ & $\mathrm{HL}_{3}$ & $\mathrm{FPL}_{3}$ & $\mathrm{HL}_{3}$ & $\mathrm{FPL}_{3}$ & $\mathrm{HL}_{3}$ & $\mathrm{FPL}_{3}$ & $\mathrm{HL}_{3}$ & $\mathrm{FPL}_{3}$ & $\mathrm{HL}_{3}$ \\
\hline November & 40 & & 48 & & 10 & & 0 & & 2 & \\
\hline December & 30 & 45 & 58 & 35 & 1 & 5 & 11 & 15 & 0 & 0 \\
\hline January & 72 & 70 & 22 & 15 & 5 & 5 & 0 & 10 & 1 & 0 \\
\hline February & 42 & 42 & 36 & 36 & 2 & 1 & 12 & 13 & 8 & 8 \\
\hline March & 20 & 33 & 80 & 33 & 0 & 0 & 0 & 34 & 0 & 0 \\
\hline April & 15 & $23^{\circ}$ & 62 & 50 & 0 & 0 & 23 & 27 & 0 & 0 \\
\hline May & 22 & 8 & 78 & 64 & 0 & 0 & 0 & 28 & 0 & 0 \\
\hline June & 0 & 0 & 100 & 100 & 0 & 0 & 0 & 0 & 0 & 0 \\
\hline
\end{tabular}

* Trichostro.: Trichostrongylus; Oesophag.: Oesophagostomum.

Table I. - Mean percentage of $\mathrm{L}_{3}$ genera recovered from initial culture of faecal samples from the donor cattle and from faecal pats ( $\mathrm{FPL}_{3}$ ) deposited in October, November and December. Mean percentage of $L_{3}$ genera recovered from herbage from the same month trials ( $\mathrm{L}_{3}$ ). 


\begin{tabular}{|c|c|c|c|c|c|c|c|c|c|c|}
\hline \multirow{2}{*}{$\begin{array}{l}\text { Oct./Nov./Dec. } \\
\text { Faecal culture }\end{array}$} & \multicolumn{2}{|c|}{ Ostertagia } & \multicolumn{2}{|c|}{ Cooperia } & \multicolumn{2}{|c|}{ Trichostro.* } & \multicolumn{2}{|c|}{ Haemonchus } & \multicolumn{2}{|c|}{ Oesophag.* } \\
\hline & \multicolumn{2}{|c|}{23} & \multicolumn{2}{|c|}{15} & \multicolumn{2}{|c|}{6} & \multicolumn{2}{|c|}{54} & \multicolumn{2}{|c|}{2} \\
\hline & $\mathrm{FPL}_{3}$ & $\mathrm{HL}_{3}$ & $\mathrm{FPL}_{3}$ & $\mathrm{HL}_{3}$ & $\mathrm{FPL}_{3}$ & $\mathrm{HL}_{3}$ & $\mathrm{FPL}_{3}$ & $\mathrm{HL}_{3}$ & $\mathrm{FPL}_{3}$ & $\mathrm{HL}_{3}$ \\
\hline February & 33 & 38 & 10 & 10 & 10 & 14 & 44 & 38 & 3 & 0 \\
\hline March & 26 & 22 & 8 & 12 & 18 & 28 & 48 & 38 & 0 & 0 \\
\hline April & 25 & 36 & 15 & 27 & 20 & 8 & 40 & 25 & 0 & 4 \\
\hline May & 30 & 34 & 13 & 14 & 12 & 17 & 45 & 35 & 0 & 0 \\
\hline June & 50 & 15 & 33 & 29 & 10 & 36 & 7 & 18 & 0 & 2 \\
\hline July & 50 & 43 & 30 & 25 & 15 & 15 & 5 & 17 & 0 & 0 \\
\hline August & 43 & 55 & 29 & 22 & 20 & 11 & 8 & 12 & 0 & 0 \\
\hline September & 75 & 60 & 0 & 25 & 25 & 15 & 0 & 0 & 0 & 0 \\
\hline
\end{tabular}

* Trichostro.: Trichostrongylus; Oesophag.: Oesophagostomum.

Table II. - Mean percentage of $\mathrm{L}_{3}$ genera recovered from initial culture of faecal samples from donor cattle and from faecal pats $\left(\mathrm{FPL}_{3}\right.$ ) deposited in January, February and March. Mean percentage of $\mathrm{L}_{3}$ genera recovered from herbage from the same month trials $\left(\mathrm{H}_{3}\right)$.

In general, Cooperia was the most prevalent genus in faecal pats and herbage from spring deposits at the end of the summer (Table I). In summer deposits of faecal pats and herbage Haemonchus was the most prevalent genus until mid-autumn, then followed by Ostertagia until the end of the winter (Table II).

\section{DEVELOPMENT TO INFECTIVE LARVAE}

In general, the development of eggs to infective larvae was rapid and took no more than two weeks. The eggs disappeared from the pats within 15 days. In most of the trials, the peak recoveries of larvae from faecal pats were obtained immediately within 15-21 days. However, in the trials begun from late spring to early summer (Nov., Dec., Jan.) the time for development to $L_{3}$ was reduced to 8-10 days.

\section{SURVIVAL OF INFECTIVE LARVAE}

The recovery of infective larvae in each trial from faecal pats, herbage and soil are indicated in Figures 2 and 3. A summary of the average number of $\mathrm{L}_{3}$ per $\mathrm{g}$ recovered from faecal pats and the percentage of $\mathrm{L}_{3}$ recovered, expressed as a proportion of the initial number of eggs estimated to be in each faecal pat deposition trial are given in Table III. Low numbers of $\mathrm{L}_{3}$ survived during the spring-summer high temperatures and drought of 1994-1995. A low percentage of $\mathrm{L}_{3}$ survived from November/94 $\left(0.5 \% \mathrm{~L}_{3}\right)$ and January/95 $(0.06 \%$ $\mathrm{L}_{3}$ ) respectively to the following autumn and winter (Fig. 2). Larvae in faecal pats deposited in October-1995 survived until July 1996, during 283 days (Fig. 3). This was the maximal length of time during which $\mathrm{L}_{3}$ were recovered from the dried faecal pats. From the faecal pats deposited in late summer, recovered $\mathrm{L}_{3}$ persisted until late winter - early spring.
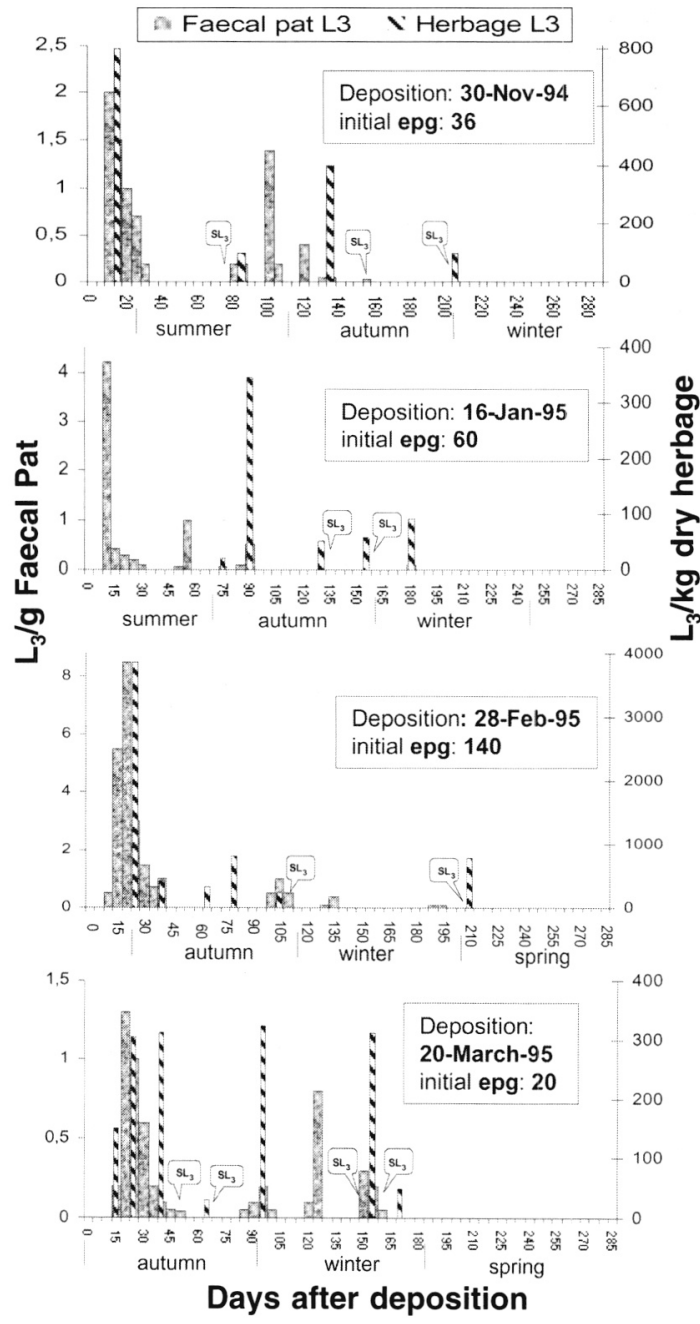

Fig. 2. - Concentration of infective larvae in faecal pats $\left(L_{3}\right.$ per $g$ of dry faecal pat) and herbage ( $\mathrm{L}_{3}$ per kg of dry matter) resulting from pats deposited in November 1994, January, February and March 1995. Detection of $\mathrm{L}_{3}$ from soil samples $\left(\mathrm{SL}_{3}\right)$ and initial epg of the faecal deposition is also indicated. 


\begin{tabular}{|c|c|c|c|c|c|c|c|}
\hline \multirow[b]{2}{*}{ Faecal pat deposition } & \multirow[b]{2}{*}{ Initial epg } & \multicolumn{6}{|c|}{$\begin{array}{l}\text { Percentage of } L_{3} \\
\text { Period of days following the faecal pat deposition }\end{array}$} \\
\hline & & $8-20 \mathrm{~d}$ & $21-50 \mathrm{~d}$ & $51-100 \mathrm{~d}$ & $101-150 \mathrm{~d}$ & $151-200 \mathrm{~d}$ & $>201 \mathrm{~d}$ \\
\hline \multirow[t]{2}{*}{ 30-Nov-94 } & 36 & 1.98 & 0.68 & 0.90 & 0.18 & 0.011 & \\
\hline & & $5.5 \%$ & $1.9 \%$ & $2.5 \%$ & $0.5 \%$ & $0.03 \%$ & \\
\hline \multirow[t]{2}{*}{ 16-Jan-95 } & 60 & 4.20 & 0.96 & 0.48 & 0.04 & 0.012 & \\
\hline & & $7 \%$ & $1.6 \%$ & $0.8 \%$ & $0.06 \%$ & $0.02 \%$ & \\
\hline \multirow[t]{2}{*}{ 28-Feb-95 } & 140 & 8.40 & 2.94 & 1.54 & 0.98 & 0.42 & 0.10 \\
\hline & & $6 \%$ & $2.1 \%$ & $1.1 \%$ & $0.7 \%$ & $0.3 \%$ & $0.07 \%$ \\
\hline \multirow[t]{2}{*}{ 20-Mar-95 } & 20 & 1.30 & 0.01 & 0.30 & 0.80 & 0.20 & \\
\hline & & $6.5 \%$ & $5 \%$ & $1.5 \%$ & $4 \%$ & $1 \%$ & \\
\hline \multirow[t]{2}{*}{ 12-Oct-95 } & 130 & 4.16 & 6.63 & 0.91 & 1.17 & 0.60 & 0.20 \\
\hline & & $3.2 \%$ & $5.1 \%$ & $0.7 \%$ & $0.9 \%$ & $0.46 \%$ & $0.15 \%$ \\
\hline \multirow[t]{2}{*}{ 12-Dec-95 } & 40 & 2.88 & 1.00 & 0.88 & 0.05 & & \\
\hline & & $7.2 \%$ & $2.5 \%$ & $2.2 \%$ & $0.12 \%$ & & \\
\hline \multirow[t]{2}{*}{ 20-Feb-96 } & 22 & 1.30 & 0.40 & 0.11 & 0.29 & 0.20 & \\
\hline & & $5.9 \%$ & $1.8 \%$ & $0.5 \%$ & $1.3 \%$ & $0.9 \%$ & \\
\hline \multirow[t]{2}{*}{ 19-Mar-96 } & 75 & 6.32 & 7.35 & 2.10 & 0.60 & 0.06 & \\
\hline & & $8.3 \%$ & $9.8 \%$ & $2.8 \%$ & $0.8 \%$ & $0.08 \%$ & \\
\hline
\end{tabular}

Table III. - Average number of $\mathrm{L}_{3}$ per $\mathrm{g}$ recovered from faecal pats during each period, and its percentage expressed as a proportion of the initial number of eggs (epg) estimated to be in each faecal pat deposition trial.
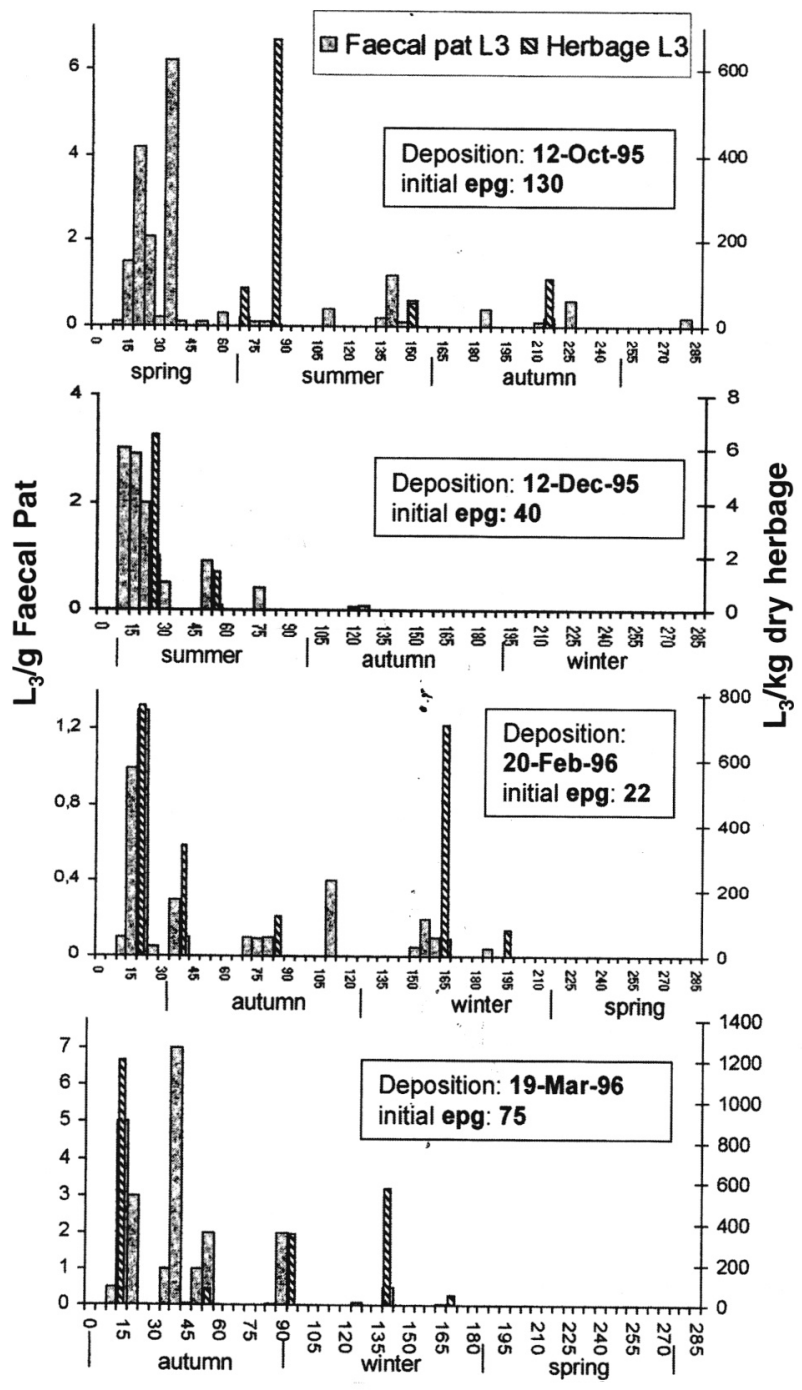

Days after deposition

\section{Migration OF INFECTIVE LARVAE}

Larvae recovery from the surrounding herbage varied according to the different weather conditions. The migration of $\mathrm{L}_{3}$ from faecal pats to herbage started 15 to 30 days after deposition according to rainfall occurrence. During spring and summer when faecal pats dried up, $\mathrm{L}_{3}$ could be recovered from the herbage only after rainfalls. The results of larvae recovered from the herbage of the trials are show in Figures 2 and 3 . Generally, maximum herbage recoveries of $\mathrm{L}_{3}$ from pats deposited in late summer occur during autumn rainfalls. The maximum number of larvae from herbage $\left(3,800 \mathrm{~L}_{3} /\right.$ dry matter $)$ was obtained for the $23^{\text {rd }}$ day of March 1995 trial deposit. Contrarily, negligible $\mathrm{L}_{3}$ herbage counts $\left(9 \mathrm{~L}_{3} /\right.$ dry matter $)$ were obtained from pats deposited in January 1996.

Infective larvae from soil were only occasionally recovered from faecal pats deposited during 1994/1995. The number of $\mathrm{L}_{3}$ detected from $10 \mathrm{~g}$ of soil, in general did not exceed 50-100 $\mathrm{L}_{3}$ and were always recovered after rainfalls

\section{DISCUSSION}

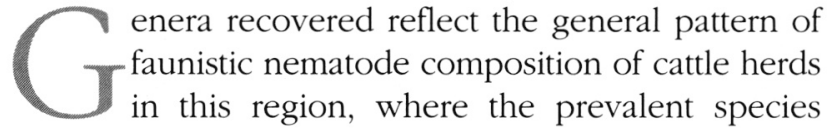

Fig. 3. - Concentration of infective larvae in faecal pats $\left(L_{3}\right.$ per $g$ of dry faecal pat) and herbage ( $\mathrm{L}_{3}$ per kg of dry matter) resulting from pats deposited in October, December 1995 and February, March 1996. Initial epg of the faecal deposition is also indicated. 
were Ostertagia ostertagi, Cooperia oncophora, Haemonchus placei, Trichostrongylus axei and Oesophagostomum radiatum (Suarez, 1990). In trials begun in spring (Oct., Nov., Dec.), Cooperia and Ostertagia were the prevalent genera, but the former persisted in the plots for long time until mid-autumn. The lower survival of Ostertagia, suggests that this genus was more susceptible to summer higher temperatures (Pandey, 1974) than Cooperia (Table I). Cooperia showed the highest persistence, according with Rose (1963), that reported a survival time for C. oncophora of two years. During trials begun in summer (Jan., Feb., Mar.), the development and survival of Haemonchus was better until mid-autumn during the first three months from deposition. It seems to be more susceptible to cold weather conditions than Ostertagia, Trichostrongylus and Cooperia that persisted in more numbers. Ostertagia was prevalent from mid-autumn until late winter (Table II).

Eggs developed to infective larvae in the faecal pats deposited in all plots. The rapid rates of development found, where preinfective stages persisted up to about 17 days can be attributed to rapid drying and progressive aeration of the pat and to high maximum mean temperatures of about $28-33^{\circ} \mathrm{C}$. Working with O. Ostertagi, Pandey (1974) and Young \& Anderson (1981) saw that under conditions where oxygen was not limiting and at temperatures over $20^{\circ} \mathrm{C}$, eggs or preinfective larvae die or develop to the infective stage within 7-8 days. Conversely, during winter months the authors (V.H. Suarez, unpublished data 1999) reported a delayed development of 15-45 days when the minimum mean air temperature was below $4^{\circ} \mathrm{C}$ and the pats have a slower rate of drying. Rossanigo \& Gruner (1994) show that temperature was the most important factor in the development rate of the cattle nematode species, because there is sufficient moisture in freshly faeces.

In this experiment the rain was necessary for $\mathrm{L}_{3}$ detection on the herbage, and no migration of infective larvae occurred in its absence during spring and summer periods. These observations coincide with those of Williams \& Bilkovick (1973) in Louisiana. In agreement with our results, Pandey (1974) reported that when weather was dry, pats became hard, dry and crusty and therefore soon after $\mathrm{L}_{3}$ development no migration could occur. Few experiments have indicated that infective larvae are dispersed by rain splash droplets (Gronvold, 1984). Young \& Anderson (1981) and Durie (1961) found that rainfalls up to 20 and $25 \mathrm{~mm}$ are necessary to allow migration from pats. In our case larvae were detected from herbage after falls of $12-20 \mathrm{~mm}$.

In the trials started during the spring months (Oct., Nov., Dec.), maximum larval herbage recoveries coincided with the first rainfalls on the newly exposed faecal pats. Despite this important and immediate larvae translation to the herbage, a small number of $\mathrm{L}_{3}$ persisted during the 1994-1995 drought period until the autumn within the faecal pats. According with reports of Goldberg (1970), high temperatures and evaporation rates were probably responsible for the death of most larvae on herbage. Barger et al., (1984), observed that larval survival in faecal pats was enhanced by dry periods as may possibly happen in this study with spring faecal depositions. Our results showed that low numbers of infective larvae from spring contamination survived the summer in faecal pats and could be available in the herbage after the autumn rains. Contrarily of those preceding mentioned reports, negligible number of $\mathrm{L}_{3}$ was recovered from pats deposited during December 1995 in late spring (Fig. 3), that were exposed to successive rainfall periods alternated with high temperatures during 1996 summer. This absence of repetitive results show the irregularity weather conditions during summer in this region. Probably during summer, larvae that were translated in waves by the rain died as the successive moisture of the pat or the surrounding herbage subsequently dried. During dry summer periods, no $\mathrm{L}_{3}$ were recovered from pats in absence of rains until the re-establishment of moist conditions. Perhaps, $\mathrm{L}_{3}$ became desiccated and non motile during dry conditions and survived in an anhydrobiosis state (Todd et al., 1977, Demeure et al., 1979) in the central part of the pat, and it is unlikely that such $\mathrm{L}_{3}$ would be recovered using the techniques employed in this study. Then with moist conditions, $\mathrm{L}_{3}$ would be re-hydrated, motility restored and the larvae were then be able to be recovered with Baermann techniques.

The largest $\mathrm{L}_{3}$ recoveries from herbage were obtained early in the autumn from pats deposited during late summer after abundant rainfalls. This autumn high level of infective larvae, not necessarily associated with rainfall, coincided with previous results in this region (Suarez, 1990), about contamination patterns, where $\mathrm{L}_{3}$ availability for weaned calves was high during autumn

The irregular rate of $\mathrm{L}_{3}$ recovery from soil samples during the trials and the fact that, only from 1994-1995 period, $\mathrm{L}_{3}$ were detected, make results not clear to be interpreted. Gruner et al. (1982) showed that active migrations through the soil is favoured according to the amount of soil water content. Therefore, the recovery of $\mathrm{L}_{3}$ after rainfalls may be favoured by the increase of soil moisture. Borgsteede \& Boogaard (1983) in the same line with our observations, found very few larvae in the soil and concluded that survival in the soil was negligible.

In conclusion, results show that eggs deposited from February to March make the most important herbage infestation since late summer to autumn and provide 
the source of infections for weaned calves or yearling fattening cattle. Likewise, the possibility of considerable infections occurring in late spring-summer would also be likely as in periods of frequent heavy rainfall associated with young weaned calves or high stoking rates on permanent pastures. The mean persistence of larvae detected in pats or herbage was around 200 days from deposition. In general, spring-summer condition was associated with rapid development and translation of larvae to herbage, but also with low pat or herbage larvae detection after initial recoveries.

\section{ACKNOWLEDGEMENTS}

We wish to thank to Nelson Zentt and Carina Bonetti for their assistance.

\section{REFERENCES}

BAERMANN G. Eine einfache methode zur auffindung von Ankylostomum (Nematoden) larven in erdproben. Geneeskundig Tidjschrift root Nederlandsch-Indie, 1917, 57, 131137.

Barger I.A., Lewis R.J. \& Brown G.F. Survival of infective larvae of nematode parasites of cattle during drought. Veterinary Parasitology, 1984, 14, 143-152.

Borgsteede F.H.M. \& Boogand G. Survival of trichostrongylid eggs and larvae in soil. Tijdschrift vor Diergeneeskunde, 1983, 108, 439-442.

Demeure Y., Freckman D.W. \& VAn Gundy S.D. In vitro response of four species of nematodes to desiccation and discussion of this and related phenomena. Revue de Nématologie, 1979, 2 (2), 203-210.

DuRIE P.H. Parasitic gastro-enteritis of cattle: the distribution and survival of infective strongyle larvae on pasture. Australian Journal of Agricultural Research., 1961, 12, 12001211.

GOLDBERG A. Development and survival on pasture of gastrointestinal nematode of cattle: summer contamination. Proceedings of the Helminthological Society, 1970, 37 (2), 166-169.

GRONvold J. Rain splash dispersal of third-stage larvae of Cooperia spp. (Trichostrongylidae). Journal of Parasitology, 1984, 70 (6), 924-926.

Gruner L., Mauleon H. \& Sauve C. Migrations of trichostrongyle infective larvae experiments with ovine parasites in soil. Annales de Recherche Vétérinaire, 1982, 13 (1), 5159.

PANDEY V.S. Ecological observations on the free-living stages of Ostertagia ostertagi. Annales de Research Vétérinaire, 1974,5 (3), 261-279.

RoBerTS F.H.S. \& O'SulLivan P.J. Methods for egg counts and larval cultures for strongyles infecting the gastrointestinal tract of cattle. Australian Journal of Agricultural Research, 1949, 1, 99-103.
Rose J.H. Ecological observations and laboratory experiments on the free-living stages of Cooperia oncophora. Journal of Comparative Pathology, 1963, 73, 285-296.

Rossanigo C.E. \& GrunEr L. Relative effect of temperature and moisture on the development of strongyle eggs to infective larvae in bovine pats in Argentina. Veterinary Parasitology, 1994, 55, 317-325.

STEFFAn P.E. \& Fiel C.A. Bioecología de los nematodes gastrointestinales. II supervivencia y variación estacional de las larvas en las pasturas. Revista Argentina de Producción Animal, 1986, S1, 139-140.

SuAREZ V.H. Inhibition patterns and seasonal availability of nematodes for beef cattle grazing on Argentina's Western Pampas. International Journal for Parasitology, 1990, 20, 1031-1036

Suarez V.H. Diagnóstico de las parasitosis internas de los rumiantes en la región de invernada. Técnicas e Interpretación. Boletín de Divulgación Técnica (INTA-Anguil), 1997, 56, 50 p.

Suarez V.H., Ciminari O.E., Bedotti D.O., Busetti M.R \& BELLO E.M. Epidemiology, effects and control of nematode infection on Zebucrossbred, Hereford and Hereford $\mathrm{x}$ Brahman calves on Argentina's Western Pampas. Veterinary Parasitology, 1990, 35, 7991.

Suarez V.H., Lorenzo R.M., Busetti M.R. \& SANTucho G.M. Physiological and parasitological responses to nematode infections of fattening cattle in the western pampas of Argentina. Veterinary Parasitology, 1999, 81, 137-148

TodD K.S., LEvine N.D. \& WAGHER B.N. Effect of repeated desiccation on survival of infective Cooperia punctata larvae. The Journal of Parasitology, 1977, 43 (5), 956-957

Williams J.C. \& Bilкоvick F.R. Distribution of Ostertagia ostertagi infective larvae on herbage pasture. American Journal of Veterinary Research, 1973, 34 (10), 1337-1344.

YOUNG R.R. \& ANDERSON N. The ecology of the free-living stages of Ostertagia ostertagi in a winter rainfall region. Australian Journal of Agricultural Research, 1981, 32, 371-388.

Reçu le 7 février 2000 Accepté le 20 juillet 2000 